\title{
Straightforward synthesis of ferrocenyl allylic thioethers.
}

\author{
Rafika Bouchene, ${ }^{a, b, c, d}$ Jean-Claude Daran, ${ }^{a, b}$ Rinaldo Poli, ${ }^{a, b, e}$ Eric Deydier, ${ }^{* a, b, f}$ \\ Sofiane Bouacida, ${ }^{c d}$ Eric Manoury $* a, b$
}

${ }^{a}$ CNRS, LCC (Laboratoire de Chimie de Coordination), 205 route de Narbonne, BP 44099, F-31077 Toulouse Cedex 4, France CNRS. Fax: +33-561553003; Tel: +33-561333174; Emails: eric.deydier@iut-tlse3.fr; eric.manoury@lcc-toulouse.fr.

${ }^{b}$ Université de Toulouse, UPS, INPT, F-31077 Toulouse Cedex 4, France

${ }^{c}$ Département Sciences de la Matière, Faculté des Sciences Exactes, Université Oum El Bouaghi, 04000, Algeria

${ }^{d}$ Unité de Recherche de Chimie Moléculaire et Structurale CHEMS, Université Mentouri, Constantine, Algeria.

${ }^{\mathrm{e}}$ Institut Universitaire de France, 1, rue Descartes, 75231 Paris Cedex 05, France.

${ }^{f}$ IUT A Paul Sabatier, Département de Chimie, Avenue Georges Pompidou, CS 20258, F81104 Castres Cedex, France

\begin{abstract}
The new ferrocenyl allylic thioethers $\mathrm{FcCH}=\mathrm{CHCH}_{2} \mathrm{SR}$ (2a-e) and $\mathrm{FcCH}(\mathrm{SR}) \mathrm{CH}=\mathrm{CH}_{2}$ (3a-e) $\left(\mathrm{R}=\mathrm{Ph}, \mathbf{a} ; 2\right.$-naphthyl, b; 3,5- $\left.\mathrm{C}_{6} \mathrm{H}_{3} \mathrm{Me}_{2}, \mathbf{c} ; i \mathrm{Pr}, \mathbf{d} ; t \mathrm{Bu}, \mathbf{e}\right)$ were synthesized in good yields from the ferrocenyallylammonium salt $[\mathbf{1}]^{+} \mathrm{I}^{-}$and the corresponding thiol RSH. With sufficiently strong bases to fully deprotonate the thiol, good to excellent regioselectivities (8899\%) in favor of the linear isomer $\mathbf{2}$ were obtained. The molecular structures of $\mathbf{2} \mathbf{a}$ and $\mathbf{2} \mathbf{b}$ were obtained by X-ray diffraction on monocrystals. A mechanistic proposal based on experimental data and supported by calculations is also presented, underlying the role of the base in the reaction regioselectivity.
\end{abstract}


This article is dedicated to Pr Carlo Mealli.

\section{Introduction}

In the last decades, many efforts have been devoted to the synthesis of allyl thioethers, $1,2,3,4,5,6,7,8,9,10,11,12,13$ because these compounds may have interesting properties in many areas such as biochemistry and medicinal chemistry, ${ }^{14,15}$ materials science ${ }^{16}$ or synthetic organic chemistry as synthetic intermediates. ${ }^{17,18,19,20,21,22}$ Despite the huge interest for ferrocene derivatives in many areas such as catalysis, , $2,24,25,26,27,28,29,30$ supramolecular chemistry $^{31,32}$ and sensing, and medicinal chemistry, ${ }^{33,34}$ no ferrocene-containing allyl thioethers have been described so far to the best of our knowledge. In this article, we wish to present the synthesis of the first members of this thioether family.

\section{Results and discussion}

We have recently described a new and efficient synthesis of ferrocenylamines starting from the ferrocenyallylammonium salt $[\mathbf{1}]^{+} \mathrm{I}^{-}{ }^{-35}$ In this contribution we present the reaction between $[\mathbf{1}]^{+}{ }^{-}$and thiol nucleophiles (see scheme 1 ).

Scheme 1: reaction of thiol with ammonium $[1]^{+}$.

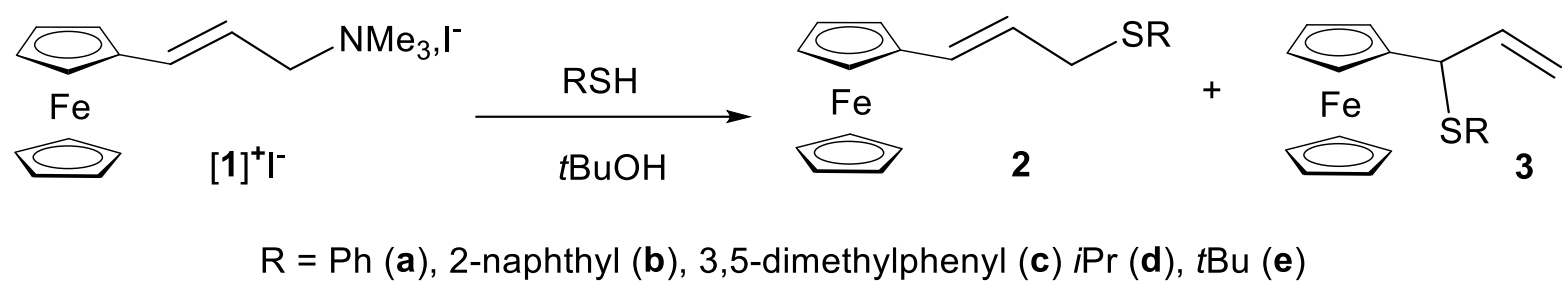

The reactions were carried out in tert-butanol at $90^{\circ} \mathrm{C}$. Under these conditions with thiophenol as nucleophile, the $[\mathbf{1}]^{+} \mathrm{I}^{-}$conversion was complete in $16 \mathrm{~h}$ to yield the desired ferrocenyl allyl thioethers in good yields as a mixture of the two regioisomers $\mathbf{2 a}$ and $\mathbf{3 a}$ in nearly equimolar amounts (Scheme 1; Table 1, entry 1). This observed regioselectivity may result either from the selectivity of the thiol attack on the ammonium cation $[\mathbf{1}]^{+}$or from a rearrangement of the sulfonium intermediates $[\mathbf{5 a}]^{+}$and $[\mathbf{6 a}]^{+}$via a carbocation intermediate before deprotonation (see Scheme 2), as proposed for similar reactions of [1] ${ }^{+}$with amines as 
nucleophiles. ${ }^{35}$ We suppose that, once formed, the products are stable with respect to isomerization in the presence of ammonium cations.

Since sulfoniums are very strong acids, ${ }^{36,37,38,39}$ we presume that they may be very efficiently deprotonated by the trimethylamine concomitantly produced in the nucleophilic substitution (Scheme 2, base $=\mathrm{NMe}_{3}$ ), which would then prevent the interconversion at the level of the sulfonium intermediates. However, it is not possible to completely rule out the possibility of a very fast equilibration between the sulfonium cations. Therefore, we have repeated the reaction in the presence of an external base to potentially accelerate the sulfonium deprotonation.

Scheme 2: Possible pathways leading to the $\mathbf{2 a / 3 a}$ product distribution.

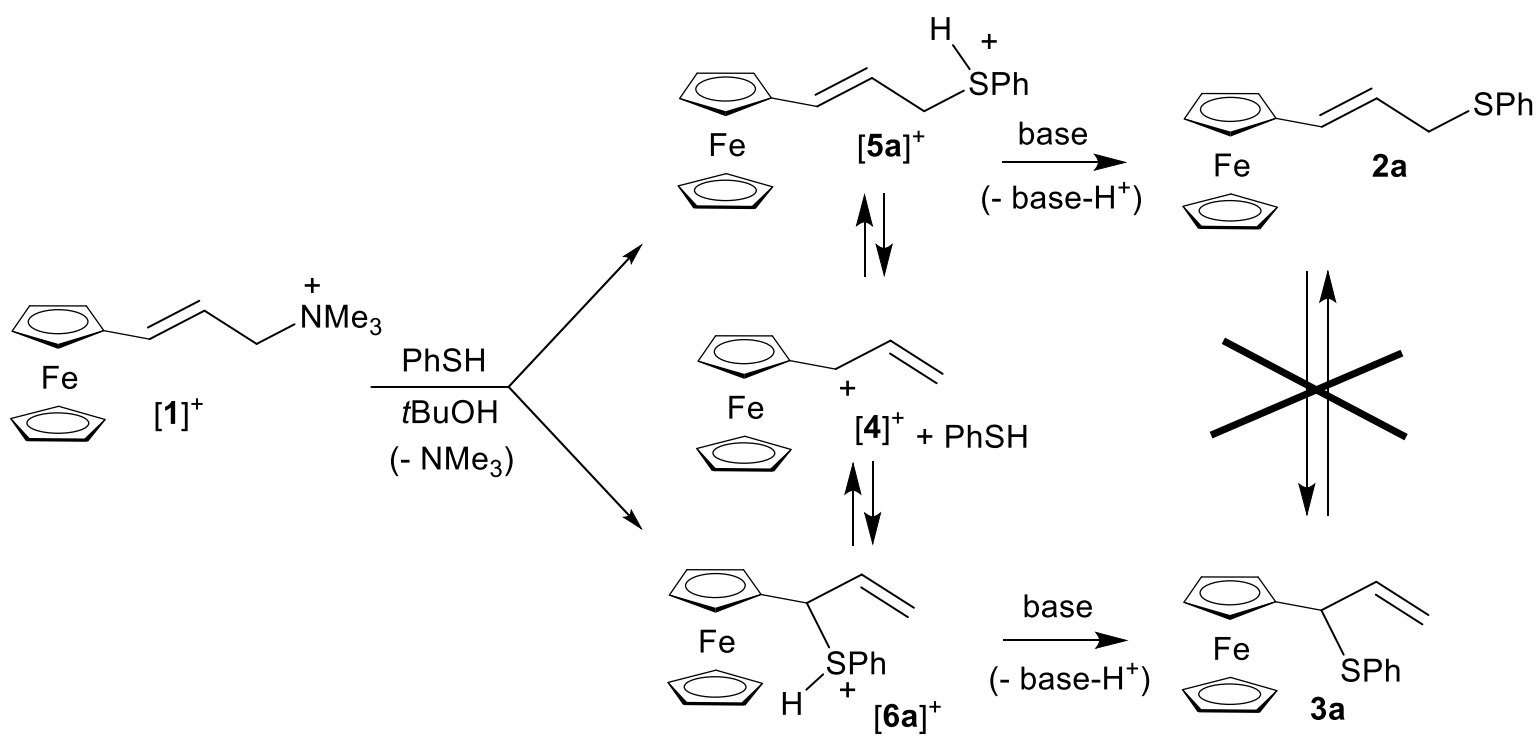

When potassium carbonate was added to the reaction mixture, the regioselectivity was almost completely shifted in favor of the linear regioisomer 2a. Carbonate is actually sufficiently basic to deprotonate thiophenol (the $\mathrm{p} K_{\mathrm{a}}$ values of $\mathrm{PhSH}$ and $\mathrm{HCO}_{3}{ }^{-}$in water are 6.5 and 10.3 , respectively $)^{40}$ to produce $\mathrm{PhS}^{-}$. Hence, the nature of the nucleophile attacking the starting compound $[\mathbf{1}]^{+}$has changed. We propose that under these conditions the nucleophilic substitution rather occurs by a $S_{N} 2$-type reaction with a regioselectivity in favor of the linear isomer $\mathbf{2 a}$ because the carbon atom in the $\alpha$ position relative to the $\mathrm{N}$ atom is more electrophilic than the $\gamma-\mathrm{C}$ atom. ${ }^{41}$

In the presence of sodium carbonate, excellent regioselectivities in favor of the linear regioisomers $\mathbf{2 b}$ and $\mathbf{2 c}$ were also obtained using other arylthiols as nucleophiles (see table 1, 
entries 3 and 4), whereas the regioselectivities were much lower for the reactions with alkylthiols (see table 1, entries 5 and 7). In fact, sodium carbonate is not sufficiently basic to fully deprotonate isopropylthiol $\left(\mathrm{p} K_{\mathrm{a}}=10.86\right)^{40}$ and tert-butylthiol $\left(\mathrm{p} K_{\mathrm{a}}=11.06\right){ }^{40}$ It was therefore decided to use a stronger base, strong enough to fully deprotonate these thiols, namely potassium tert-butylate, $t \mathrm{BuOK}\left(\mathrm{p} K_{\mathrm{a}} \text { of } t \mathrm{BuOH}=16.9\right)^{42}$. Indeed, this base led to higher regioselectivities in favor of the linear isomers $\mathbf{3 d}$ and $\mathbf{3 e}$ (table 1, entries 6 and 8).

Table 1. Reactions of RSH with $[\mathbf{1}]^{+} \mathrm{I}^{-}{ }^{a}$

\begin{tabular}{|c|c|c|c|c|}
\hline Entry & $\mathbf{R}$ & $\mathbf{B a s e}$ & $\mathbf{2 : 3 / \%}$ & Yield (2, 3)/\% $^{c}$ \\
\hline 1 & $\mathrm{Ph}$ & - & $55: 45$ & 48,22 \\
\hline 2 & $\mathrm{Ph}$ & $\mathrm{Na}_{2} \mathrm{CO}_{3}{ }^{d}$ & $99: 1$ & 72,0 \\
\hline 3 & $2-\mathrm{Naphthyl}$ & $\mathrm{Na}_{2} \mathrm{CO}_{3}{ }^{d}$ & $98: 2$ & 85,0 \\
\hline 4 & $3,5-\mathrm{C}_{6} \mathrm{H}_{3} \mathrm{Me}_{2}$ & $\mathrm{Na}_{2} \mathrm{CO}_{3}{ }^{d}$ & $99: 1$ & 66,0 \\
\hline 5 & $i \mathrm{Pr}$ & $\mathrm{Na}_{2} \mathrm{CO}_{3}{ }^{d}$ & $42: 58$ & 36,50 \\
\hline 6 & $i \mathrm{Pr}$ & $t \mathrm{BuOK}^{e}$ & $93: 7$ & 89,4 \\
\hline 7 & $t \mathrm{Bu}$ & $\mathrm{Na}_{2} \mathrm{CO}_{3}{ }^{d}$ & $46: 54$ & 42,52 \\
\hline 8 & $t \mathrm{Bu}$ & $t \mathrm{BuOK}^{e}$ & $83: 17$ & 73,14 \\
\hline
\end{tabular}

${ }^{a}$ Conditions: $[1]^{+} \mathrm{I} / \mathrm{RSH}=1: 2$, in $t \mathrm{BuOH}, 90^{\circ} \mathrm{C}, 16 \mathrm{~h} .{ }^{b}$ Determined by ${ }^{1} \mathrm{H}$ NMR of the crude product mixture. ${ }^{c}$ Isolated after chromatographic separation (see Experimental details). $\mathrm{Na}_{2} \mathrm{CO}_{3} /[\mathbf{1}]^{+} \mathrm{I}^{-}=20 .{ }^{e}[\mathbf{1}]^{+} \mathrm{I}^{-} / \mathrm{RSH}=1: 3, t \mathrm{BuOK} /[\mathbf{1}]^{+} \mathrm{I}^{-}=2$.

\subsection{Crystallographic studies.}

Single crystals of compounds $\mathbf{2} \mathbf{a}$ and $\mathbf{2} \mathbf{b}$, suitable for X-ray diffraction analysis, were obtained by slow diffusion of hexane in dichloromethane solutions. Both compounds present closely related structures based on a ferrocene moiety, with one of the two cyclopentadienyl rings substituted by an allyl thioether chain as shown in Figures 1 and 2. The structure of compound 2a features two crystallographically independent molecules A and B within the asymmetric unit. A molecular fitting ${ }^{43}$ (Figure 3) reveals that these are well superimposed and their bond lengths and angles (selected values are compared in Table 2) are roughly identical. 


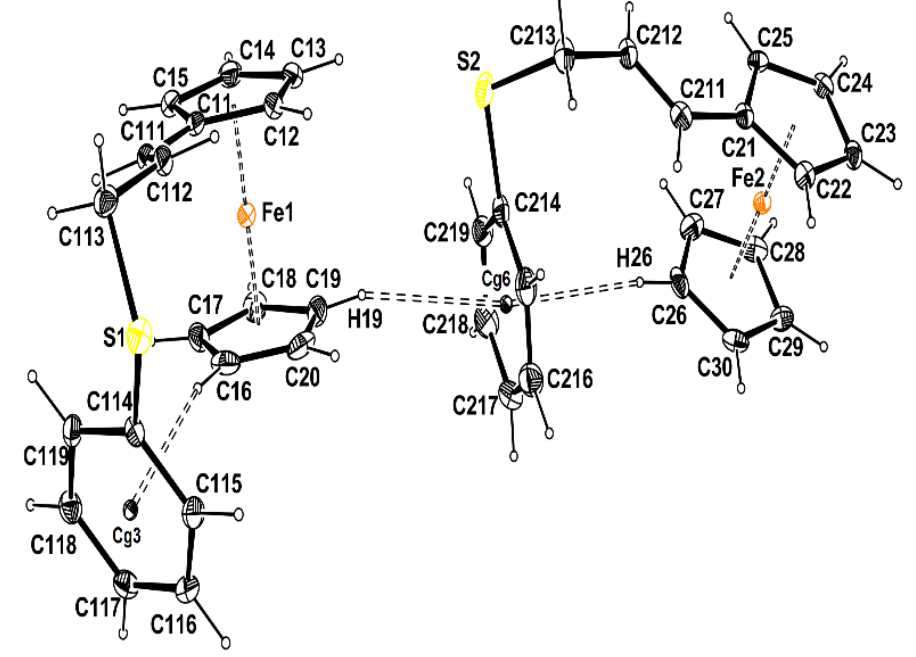

Figure 1. Molecular view of compound 2a with the atom labelling scheme. Ellipsoids are drawn at the 50\% probability level. $\mathrm{H}$ atoms are represented as small circle of arbitrary radii. The two molecules A and B building the asymmetric unit are represented for the sake of clarity.

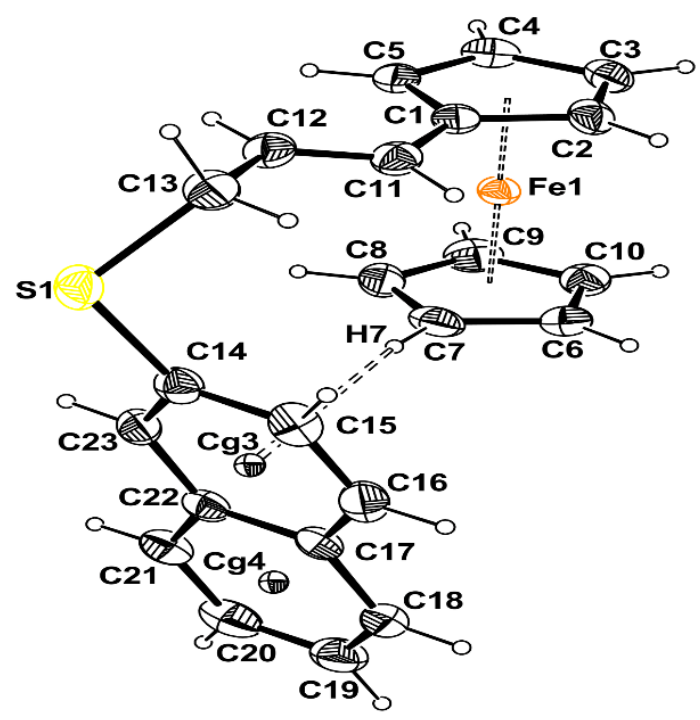

Figure 2. Molecular view of compound $\mathbf{2 b}$ with the atom labelling scheme. Ellipsoids are drawn at the $50 \%$ probability level. $\mathrm{H}$ atoms are represented as small circle of arbitrary radii.

The Cp rings are nearly eclipsed in both compounds with twist angles $\tau$ of $1.40(38)^{\circ}, 0.89(40)^{\circ}$ and $0.95(16)^{\circ}$ for $\mathbf{2 a}(\mathrm{A}), \mathbf{2} \mathbf{a}(\mathrm{B})$ and $\mathbf{2 b}$ respectively. The most interesting feature is the occurrence of $\mathrm{C}-\mathrm{H} \cdots \pi$ interactions between one of the $\mathrm{CH}$ groups of the unsubstituted $\mathrm{Cp}$ ring 
and the centroid of the phenyl ring directly attached to the sulfur atom within the same molecule in both $\mathbf{2 a}(\mathrm{A})(\mathrm{C} 16-\mathrm{H} 16 \cdots \mathrm{Cg} 3)$ and $\mathbf{2 a}(\mathrm{B})(\mathrm{C} 26-\mathrm{H} 26 \cdots \mathrm{Cg} 6)$, as well as across the two different molecules $\mathbf{2 a}(\mathrm{A})$ and $\mathbf{2 a}(\mathrm{B})(\mathrm{C} 19-\mathrm{H} 19 \cdots \mathrm{Cg} 6)$ (Table 3, Figure 1). In 2b, in addition to the same type of $\mathrm{CH}(\mathrm{Cp}) \cdots \mathrm{Ph}$ interaction, there is also a $\mathrm{CH} \cdots \pi$ interaction between one methylene $\mathrm{CH}$ group (C13H13A) and the symmetry-related C17-C22 phenyl ring (see table 3).

Table 2. Selected bond lengths $(\AA)$ and angles $\left({ }^{\circ}\right)$ for the structures of $\mathbf{2 a}$ and $\mathbf{2 b}$

\begin{tabular}{|c|c|c|c|}
\hline & $\mathbf{2 a}(\mathbf{A})$ & $\mathbf{2 a}(\mathbf{B})$ & $\mathbf{2 b}$ \\
\hline $\mathrm{Fe}(1)-\mathrm{Cg}(1)$ & $1.648(3)$ & $1.645(2)$ & $1.651(2)$ \\
\hline $\mathrm{Fe}(1)-\mathrm{Cg}(2)$ & $1.653(3)$ & $1.645(2)$ & $1.651(2)$ \\
\hline $\mathrm{S}(1)-\mathrm{C}(14)$ & $1.774(2)$ & $1.769(3)$ & $1.777(2)$ \\
\hline $\mathrm{S}(1)-\mathrm{C}(13)$ & $1.821(3)$ & $1.825(3)$ & $1.839(2)$ \\
\hline $\mathrm{C}(1)-\mathrm{C}(11)$ & $1.461(3)$ & $1.453(3)$ & $1.463(3)$ \\
\hline $\mathrm{C}(11)-\mathrm{C}(12)$ & $1.326(4)$ & $1.326(4)$ & $1.325(3)$ \\
\hline $\mathrm{C}(12)-\mathrm{C}(13)$ & $1.490(3)$ & $1.489(3)$ & $1.490(3)$ \\
\hline & & & 178.05 \\
\hline $\mathrm{Cg}(1)-\mathrm{Fe}(1)-\mathrm{Cg}(2)$ & $179.16(12)$ & $179.33(30)$ & $123.49(18)$ \\
\hline $\mathrm{C}(2)-\mathrm{C}(1)-\mathrm{C}(11)$ & $128.3(2)$ & $128.6(2)$ & $129.67(18)$ \\
\hline $\mathrm{C}(5)-\mathrm{C}(1)-\mathrm{C}(11)$ & $124.8(2)$ & $124.5(2)$ & $126.5(2)$ \\
\hline $\mathrm{C}(12)-\mathrm{C}(11)-\mathrm{C}(1)$ & $126.8(2)$ & $126.8(2)$ & $122.8(2)$ \\
\hline $\mathrm{C}(11)-\mathrm{C}(12)-\mathrm{C}(13)$ & $124.0(2)$ & $122.3(3)$ & $113.27(15)$ \\
\hline $\mathrm{C}(12)-\mathrm{C}(13)-\mathrm{S}(1)$ & $112.72(17)$ & $113.65(17)$ & $101.44(9)$ \\
\hline $\mathrm{C}(14)-\mathrm{S}(1)-\mathrm{C}(13)$ & $103.76(12)$ & $104.20(12)$ & \\
\hline
\end{tabular}

Table 3. Relevant C-H $\cdots \mathrm{Cg} \pi$ interactions in the structures of compounds $\mathbf{2 a}$ and $\mathbf{2} \mathbf{b}$

\begin{tabular}{|c|c|c|c|c|}
\hline \multicolumn{5}{|c|}{ Compound 2a } \\
\hline D-HיAA & D-H(A) & $\mathbf{H} \cdots \mathbf{A}(\AA)$ & $\mathbf{D} \cdots \mathbf{A}(\AA)$ & D-H $\cdots A\left(^{\circ}\right)$ \\
\hline $\mathrm{C} 16-\mathrm{H} 16 \cdots \mathrm{Cg} 3$ & 0.95 & 2.75 & $3.677(4)$ & $167.0(2)$ \\
\hline $\mathrm{C} 26-\mathrm{H} 26 \cdots \mathrm{Cg} 6$ & 0.95 & 2.84 & $3.776(4)$ & $167.5(2)$ \\
\hline 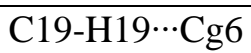 & 0.95 & 2.93 & $3.846(5)$ & $162.0(2)$ \\
\hline
\end{tabular}

symmetry code: (i) -1/4+x, 5/4-y, 3/4+z

$\mathrm{Cg} 3$ is the centroid of the $\mathrm{C} 114-\mathrm{C} 119$ phenyl ring; $\mathrm{Cg} 6$ is the centroid for the $\mathrm{C} 214-\mathrm{C} 219$ phenyl ring. 


\begin{tabular}{|l|c|c|c|c|}
\hline \multicolumn{5}{|c|}{ Compound 2b } \\
\hline \multicolumn{1}{|c|}{$\mathbf{D}-\mathbf{H} \cdots \mathbf{A}$} & $\mathbf{D}-\mathbf{H}(\stackrel{\AA}{\mathbf{A}})$ & $\mathbf{H} \cdots \mathbf{A}(\stackrel{\AA}{\mathbf{A}})$ & $\mathbf{D} \cdots \mathbf{A}(\mathbf{\AA})$ & $\mathbf{D}-\mathbf{H} \cdots \mathbf{A}\left({ }^{\circ}\right)$ \\
\hline $\mathrm{C} 7-\mathrm{H} 7 \cdots \mathrm{Cg} 3$ & 0.95 & 2.98 & $3.914(2)$ & $168.9(1)$ \\
\hline $\mathrm{C} 13-\mathrm{H} 13 \mathrm{~A} \cdots \mathrm{Cg} 44^{\mathrm{i}}$ & 0.95 & 2.83 & $3.613(2)$ & 138 \\
\hline
\end{tabular}

symmetry code: (i) -x, 1/2+y, 3/2-z

$\mathrm{Cg} 3$ is the centroid for the C14-C15-C16-C17-C22-C23 phenyl ring; $\mathrm{Cg} 4$ is the centroid of the C17-C22 phenyl ring.

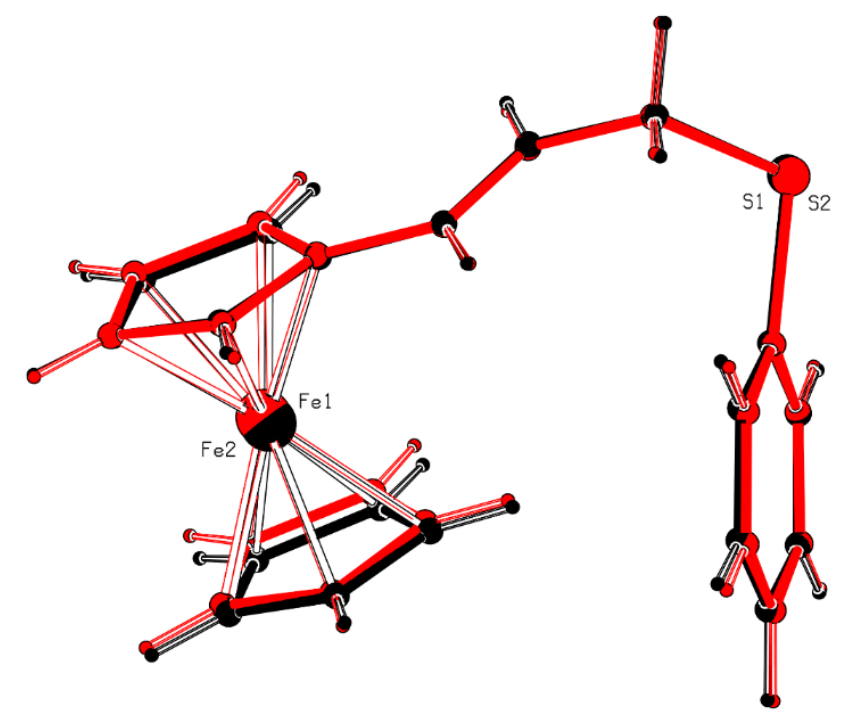

Figure 3. Molecular fitting showing the superimposed molecules (red and black) for 2a. All atoms are represented as circle.

\subsection{Calculations}

For a better understanding of the experimental results, computational studies were carried out using the B97D functional with solvent correction using the SMD polarisable continuum in ethanol $(\varepsilon=24.852)$. The computational method was first assessed by comparing the optimized geometry of the $[\mathbf{1}]^{+}$ion with the X-ray crystallographic data in the structure of $[\mathbf{1}]^{+} \mathrm{I}^{-35}$ As shown in table 4 , the theoretical and experimental values are similar, confirming the suitability of the chosen method. Slight differences may be explained by the packing effect on bond distances in the solid state (XRD), whereas the DFT geometry optimization was carried out for an isolated molecule in the polarizable continuum. 
Table 4. Comparison of selected experimental and DFT-optimized bond lengths ( $\mathrm{A})$.

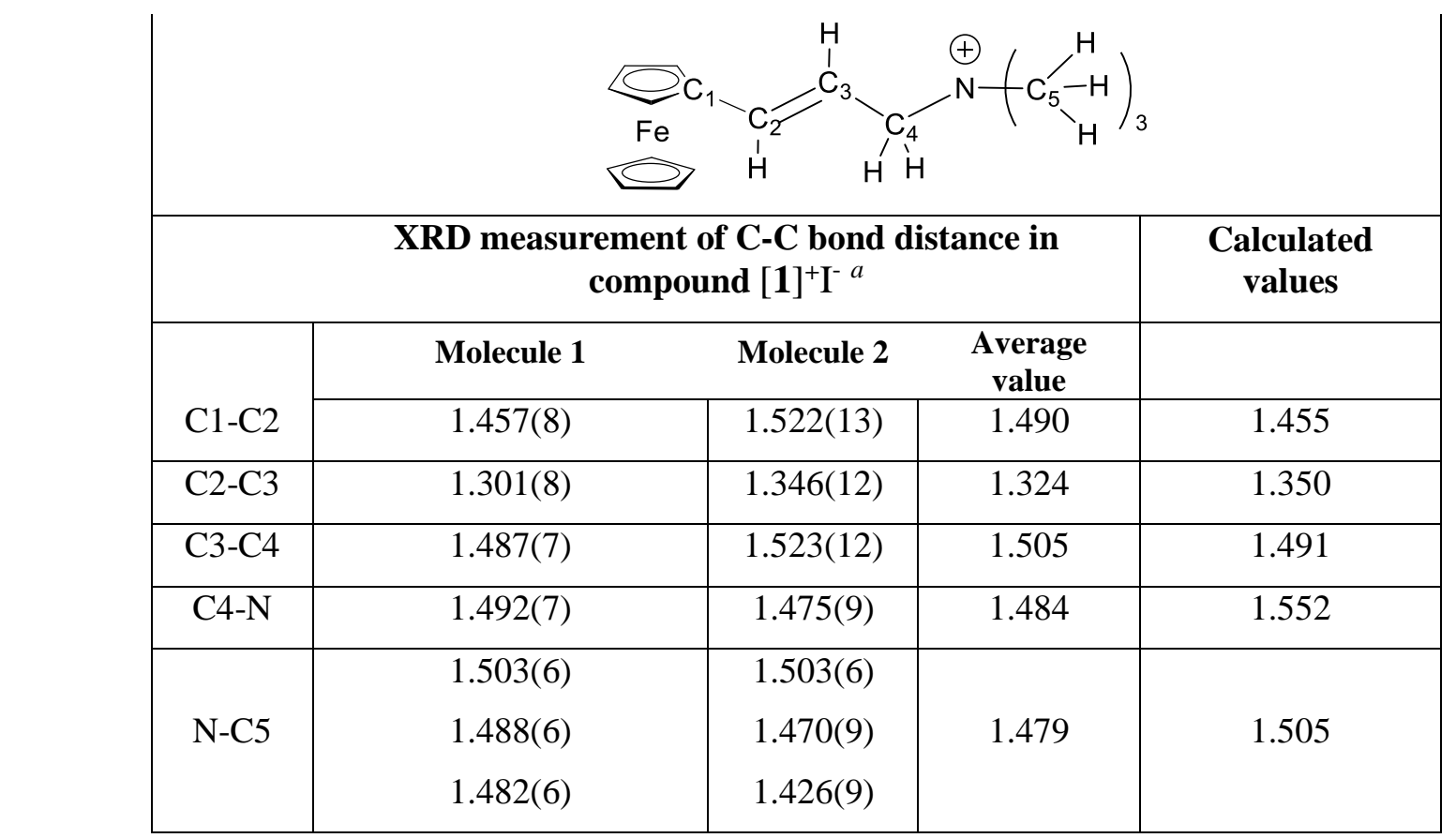

${ }^{a}$ Data taken from reference 35 .

From a mechanistic point of view, the reaction of a thiolate with the allylic ammonium ion $[1]^{+}$ should involve nucleophilic substitutions via an $\mathrm{S}_{\mathrm{N}} 1, \mathrm{~S}_{\mathrm{N}} 2$ or $\mathrm{S}_{\mathrm{N}} 2$ ' mechanism. We have investigated all these pathways (Scheme 3) using methylthiolate as a model nucleophile. The $\mathrm{S}_{\mathrm{N}} 1$ mechanism, in which the amine dissociates to yield the carbocation $[4]^{+}$, presents the highest transition state $\left(\Delta \mathrm{G}^{\ddagger}=21.9 \mathrm{kcal} \mathrm{mol}^{-1}\right)$, whereas the transition states of the $\mathrm{S}_{\mathrm{N}} 2\left(\Delta \mathrm{G}^{\ddagger}=\right.$ $\left.15.9 \mathrm{kcal} \mathrm{mol}^{-1}\right)$ and $\mathrm{S}_{\mathrm{N}} 2^{\prime}\left(\Delta \mathrm{G}^{*}=18.2 \mathrm{kcal} \mathrm{mol}^{-1}\right)$ pathways are slightly lower. These results indicate that when thiolates are present in the reaction medium, the $S_{N} 1$ pathway is disfavored. Furthermore, they indicate that the $S_{N} 2$ pathway is favored relative to the $S_{N} 2$ ' pathway, in agreement with the experimental evidence. The free enthalpy difference between the transitions states of the two bimolecular pathways, $\Delta\left(\Delta \mathrm{G}^{\ddagger}\right)=2.3 \mathrm{kcal} \mathrm{mol}^{-1}$, corresponds to a rate constant ratio $\left(\mathrm{kSN}_{\mathrm{S} 2}\right) / \mathrm{k}\left(\mathrm{SN}^{\prime}\right)$ of 24 at $90^{\circ} \mathrm{C}$ according to the Eyring equation, which translates into a $\mathbf{2 : 3}$ ratio of 96/4. This falls within the range of the experimentally observed $2: 3$ ratios for the various thiolate nucleophiles (table 1, entries 2,3,4,6 and 8). 


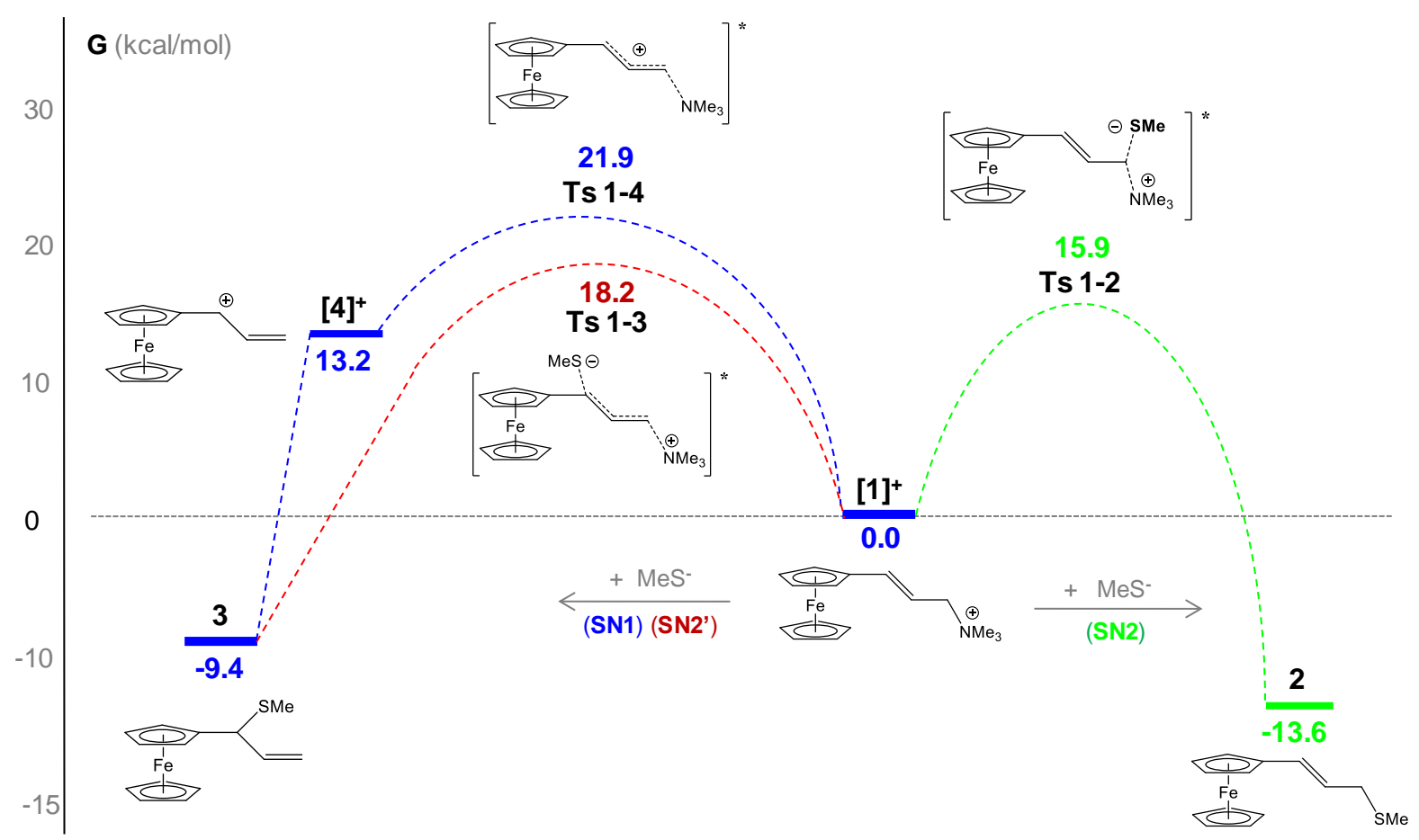

Scheme 3: Energy diagram for the reaction of methylthiolate MeS- with ammonium $\mathbf{1}^{+}$.

Upon taking a closer look at the calculations for the carbocation $[4]^{+}$, we note that the $\mathrm{C}_{3}-\mathrm{C}_{4}$ bond length is typical (1.35 $\AA$ ) for a double bond while the $\mathrm{C}_{2}-\mathrm{C}_{3}$ bond is longer $(1.44$ $\AA$ ), close to the distance expected for a single bond between two $\mathrm{sp}^{2}$ carbons. The bonding scheme in carbocation $[4]^{+}$(Figure 4 ) has therefore a large contribution from the Lewis structure given in Figure 4, with the positive charge localized on the $\mathrm{C} 2$ carbon. Moreover, the $\mathrm{C}_{1}, \mathrm{C}_{2}$, $\mathrm{C}_{3}$ and $\mathrm{C}_{4}$ atoms are within the same plane, which is bent towards the iron atom, placed at a dihedral angle of $147^{\circ}$ relative to the plane of the $\mathrm{Cp}$ ring. This bending is provoked by an interaction between $\mathrm{C}_{2}$ and the electron rich iron atom $(\mathrm{Fe}-\mathrm{C} 2=2.41 \AA$ ) (see figure 4$)$. A similar distortion has previously been observed by X-ray diffraction analysis of a ferrocenyl carbocation. $^{44}$
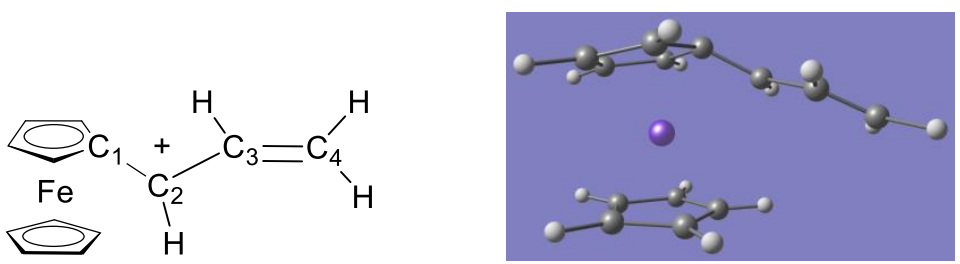

Figure 4. Bonding scheme and DFT optimized structure of carbocation $[4]^{+}$.

The computational study of the nucleophilic substitution with the neutral thiols has been realized using methylthiol as model nucleophile. Starting from the allylammonium ion $[\mathbf{1}]^{+}$, 
attack at the carbon bearing the trimethylamine fragment $\left(\mathrm{S}_{\mathrm{N}} 2\right)$ yields a transition state at very high energy $\left(\Delta \mathrm{G}^{*}=35.5 \mathrm{kcal} \mathrm{mol}^{-1}\right.$; Scheme 4$)$, much higher than the $\mathrm{S}_{\mathrm{N}} 2$ transition state with methylthiolate. Unfortunately, we were unable to locate the transition state for the $\mathrm{S}_{\mathrm{N}} 2$ ' mechanism. At any rate, this is also likely located at high energy, higher than TS1-4. These results suggest that the nucleophilic substitutions with thiols probably involve an $\mathrm{S}_{\mathrm{N}} 1$

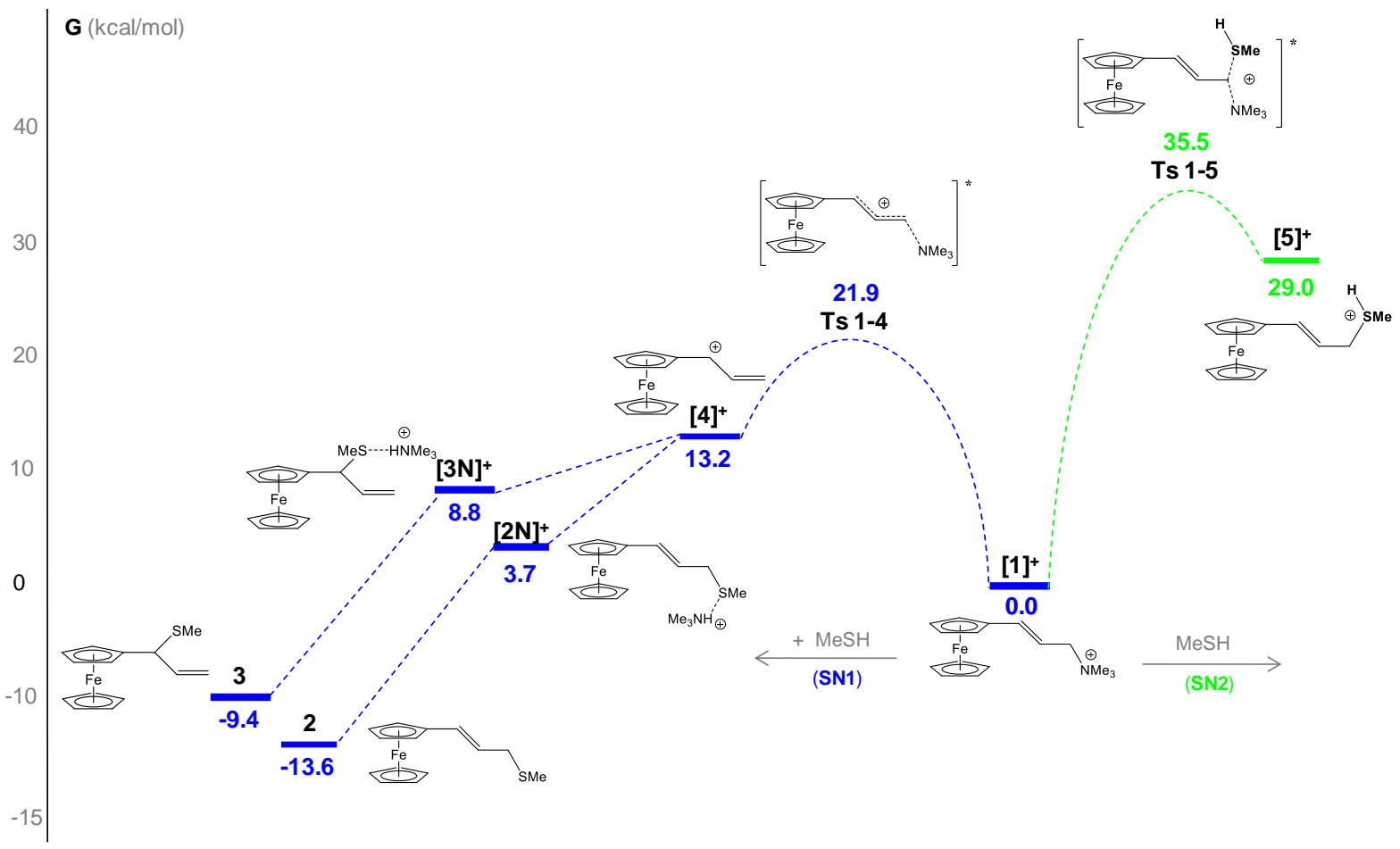

Scheme 4: Energy diagram for the reaction of methylthiol MeSH with ammonium $[\mathbf{1}]^{+}$.

The direct addition of thiols to the carbocation $[4]^{+}$yields the cationic sulfonium intermediates (see scheme 2). The geometry of the linear isomer $[5]^{+}$has been optimized and found to lie at very high energy $\left(29 \mathrm{kcal} \mathrm{mol}^{-1}\right)$ relative to $[\mathbf{1}]^{+}$, whereas the branched isomer $[6]^{+}$could not be optimized but is probably also very high in energy. The direct reaction of thiols on carbocation $[4]^{+}$is therefore very improbable. The reactions of the H-bonded $\mathrm{MeSH} \cdots \mathrm{NMe}_{3}$ complex with the substrate $[\mathbf{1}]^{+}$at both the $\alpha$ and $\gamma \mathrm{C}$ atoms have also been explored, since $\mathrm{NMe}_{3}$ would be present in solution after the initial formation of the carbocation $[4]^{+}$from $[1]^{+}$. The products of the substitution reactions are the trimethylammonium adducts $[\mathbf{3 N}]^{+}$and $[\mathbf{2 N}]^{+}$(see scheme 4 ), both found more stable than the free carbocation $[4]^{+}$. Note also that $[\mathbf{2 N}]^{+}$is much lower in energy than the corresponding sulfonium $[\mathbf{5}]^{+}$because the very acidic $\mathrm{H}^{+}$in $[\mathbf{2 N}]^{+}$has already been transferred to the nitrogen atom of the trimethylamine base, providing strong stabilization. Finally, the free thioethers $\mathbf{2}$ and $\mathbf{3}$ are the most stable species. 
In this reaction scheme, the two possible sulfonium intermediates, linear [5] $]^{+}$and branched $[\mathbf{6}]^{+}$, are, in fact, never present in the reaction mixture, ruling out the equilibration pathways presented in Scheme 2. This leads us to propose that the reaction regioselectivity (Table 1, entries 1,5 and 7) corresponds to the regioselectivity of the nucleophile addition to the intermediate carbocation, without further equilibration. Unfortunately, we did not succeed in the optimization of neither the transition states of the processes leading from $[4]^{+}$to $[\mathbf{2 N}]^{+}$and $[\mathbf{3 N}]^{+}$.

\section{Conclusions}

We have developed a synthesis of the first ferrocenyl allylic thioethers, obtained in good yields in one step from the ferrocenyallylammonium salt $[\mathbf{1}]^{+} \mathrm{I}^{-}$. In the presence of appropriate bases with sufficient strength to generate thiolate anions, interesting level of regioselectivities (88-99\%) in favor of the linear isomer were obtained. The mechanistic investigations by DFT calculations have allowed us to propose that a $S_{N} 2$ mechanism is operative with the thiolate nucleophiles, whereas a dissociative $\left(\mathrm{S}_{\mathrm{N}} 1\right)$ mechanism occurs in the presence of neutral thiols. In the latter case, the proton abstraction from the thiol by trimethylamine is concomitant with the C-S bond formation.

\section{Experimental}

\subsection{General considerations}

((2-Ferrocenylvinyl)methyl)trimethylammonium iodide, $[\mathbf{1}]^{+} \mathrm{I}-$, was synthesized by a published procedure. ${ }^{35}$ The different thiols are commercially available and have been used without prior purification (thiophenol from Acros, 99\% purity; 2-naphtylthiol from Avocado, 96\% purity; 3,5-dimethylthiophenol from Acros, 98\% purity; 2-propylthiol from Fluka, 97\% purity;. 2-methyl-2-propanethiol from Aldrich, 99\% purity). Flash chromatographies were carried out with Silicagel 60A obtained from Carlo Erba. 1D- and 2D-NMR spectra were recorded on a Bruker AV400 spectrometer. ${ }^{1} \mathrm{H}$ and ${ }^{13} \mathrm{C}$ chemicals shifts $(\delta)$ are given in ppm (the residual peak of the deuterated solvent was used as reference). Peaks are labelled as singlet $(\mathrm{s})$, doublet $(\mathrm{d})$, triplet $(\mathrm{t})$, multiplet $(\mathrm{m})$ and broad (br). The proton and carbon assignments were performed by COSY, HSQC, ${ }^{1} \mathrm{H}^{-13} \mathrm{C}$ HMBC experiments. MS spectra were performed by the mass spectrometry service of the Paul Sabatier University, Toulouse. 


\subsection{General synthesis of thioethers 2 and $\mathbf{3}$.}

Procedure A: in a Schlenk tube under argon, $103 \mathrm{mg}$ of the salt $[1]^{+} \mathrm{I}^{-}(0.25 \mathrm{mmol})$ and the desired thiol ( 2 equiv, $0.50 \mathrm{mmol}$ ) were dissolved in $8 \mathrm{ml}$ of $t \mathrm{BuOH}$. Procedure $\mathrm{B}$ : as above, plus $\mathrm{Na}_{2} \mathrm{CO}_{3}$ (530 mg, $5.0 \mathrm{mmol}, 20$ equiv). Procedure $\mathrm{C}$ : as for procedure A but with 3 equivalents of thiol $(0.75 \mathrm{mmol})$ plus $\mathrm{KO} t \mathrm{Bu}(56 \mathrm{mg}, 0.5 \mathrm{mmol}, 2$ equiv). In all cases, the reaction mixture was stirred at $90^{\circ} \mathrm{C}$ for $16 \mathrm{~h}$. After cooling back to room temperature, the reaction mixture was filtered through filter paper and the purification and product separation were carried out by flash chromatography on silicagel (petroleum ether/ diethyl ether (8/2, v/v) +1 drop of triethylamine).

\section{Reaction with PhSH}

$40 \mathrm{mg}$ of $\mathbf{2 a}(48 \%)$ and $18 \mathrm{mg}$ of $\mathbf{3 a}(22 \%)$ as yellow solids (procedure A).

$60 \mathrm{mg}$ of $\mathbf{2 a}(72 \%)$ as a yellow solid (procedure B).

(2-ferrocenylvinyl)methyl phenyl sulfide 2a: ${ }^{1} \mathrm{H}\left(400 \mathrm{MHz}, \mathrm{CDCl}_{3}\right)$ : 7.45-7.42 (2H, m, $\mathrm{Ph}$ ), 7.36-7.30 (2H, m, Ph), 7.23-7.19 (1H, m, Ph), 6.24 (1H, br d J = 15.6 Hz, CH vinyl), 5.86 (1H, $\mathrm{d}$ of $\mathrm{t}, \mathrm{J}=15.6 \mathrm{~Hz}, \mathrm{~J}=7.2 \mathrm{~Hz}, \mathrm{CH}$ vinyl), $4.29(2 \mathrm{H}$, pseudo $\mathrm{t}, \mathrm{J}=1.9 \mathrm{~Hz}$, subst Cp), 4.19 (2H, pseudo t, $\mathrm{J}=1.9 \mathrm{~Hz}$, subst Cp), $4.01(5 \mathrm{H}, \mathrm{s}, \mathrm{Cp}), 3.63\left(2 \mathrm{H}, \mathrm{dd}, \mathrm{J}=7.2 \mathrm{~Hz}, \mathrm{~J}=1.3 \mathrm{~Hz} \mathrm{C}_{2}\right)$. ${ }^{13} \mathrm{C}\left(125 \mathrm{MHz}, \mathrm{CDCl}_{3}\right): 136.0$ (s, quat. Ph), 130.5 (s, CH vinyl), 129.9 (s, Ph), 128.8 (s, Ph), 126.3 (s, Ph), 122.3 (s, CH vinyl), 82.5 (s, quat. Cp), 69.1 (s, Cp), 68.6 (s, subst. Cp), 66.7 (s, subst. Cp), 37.0 (s, $\underline{\mathrm{CH}}_{2}$-vinyl). HR MS (ESI+): 334.0476 (100\%, 334.0479 for $\left.\mathrm{C}_{19} \mathrm{H}_{18} \mathrm{FeS}: \mathrm{M}\right)$, $225.0366\left(54 \%, 225.0367\right.$ for $\left.\mathrm{C}_{13} \mathrm{H}_{13} \mathrm{Fe}: \mathrm{M}-\mathrm{SPh}\right)$

\section{Reaction with 2-naphthylthiol}

$82 \mathrm{mg}$ of $\mathbf{2 b}(85 \%)$ as a yellow solid (procedure B).

(2-ferrocenylvinyl)methyl 2-naphthyl sulfide $2 \mathbf{b}:{ }^{1} \mathrm{H}\left(400 \mathrm{MHz}, \mathrm{CDCl}_{3}\right)$ : 7.9-7.7 (4H, m, Ar), 7.55-7.4 (3H, m, Ar), 6.28 (1H, br d J = 15.5 Hz, CH vinyl), $5.90(1 \mathrm{H}, \mathrm{d}$ of $\mathrm{t}, \mathrm{J}=15.5 \mathrm{~Hz}, \mathrm{~J}=$ $7.2 \mathrm{~Hz}, \mathrm{CH}$ vinyl), 4.28 (2H, pseudo t, $\mathrm{J}=1.9 \mathrm{~Hz}$, subst $\mathrm{Cp}$ ), 4.18 (2H, pseudo $\mathrm{t}, \mathrm{J}=1.9 \mathrm{~Hz}$, subst Cp), $3.95(5 \mathrm{H}, \mathrm{s}, \mathrm{Cp}), 3.74\left(2 \mathrm{H}, \mathrm{dd}, \mathrm{J}=7.2 \mathrm{~Hz}, \mathrm{~J}=1.3 \mathrm{~Hz} \mathrm{C} \underline{\mathrm{H}}_{2}\right) .{ }^{13} \mathrm{C}\left(125 \mathrm{MHz}, \mathrm{CDCl}_{3}\right)$ : 133.7 (s, quat. Ar), 133.6 (s, quat. Ar), 131.9 (s, quat. Ar), 130.7 (s, CH vinyl), 128.3 (s, Ar), 127.9 (s, Ar), 127.8 (s, Ar), 127.1 (s, Ar), 126.5 (s, Ar), 125.7 (s, Ar), 122.0 (s, CH vinyl), 82.5 
(s, quat. Cp), 69.1 (s, Cp), 68.6 (s, subst. Cp), 66.7 (s, subst. Cp), 36.9 (s, $\underline{\mathrm{CH}}_{2}$-vinyl). HR MS (ESI+): $384.0636\left(100 \%, 384.0635\right.$ for $\left.\mathrm{C}_{23} \mathrm{H}_{20} \mathrm{FeS}: \mathrm{M}\right), 225.0371$ (46\%, 225.0367 for $\mathrm{C}_{13} \mathrm{H}_{13} \mathrm{Fe}$ : M-SAr).

\section{Reaction with 3,5-dimethylphenylthiol}

$90 \mathrm{mg}$ of $\mathbf{2 c}(66 \%)$ as a yellow solid (procedure B).

\section{(2-ferrocenylvinyl)methyl (3,5-dimethylphenyl) sulfide 2c :}

${ }^{1} \mathrm{H}\left(400 \mathrm{MHz}, \mathrm{CDCl}_{3}\right): 7.05(2 \mathrm{H}, \mathrm{s}, \mathrm{Ar}), 6.85(1 \mathrm{H}, \mathrm{s}, \mathrm{Ar}), 6.25(1 \mathrm{H}, \mathrm{t}, \mathrm{J}=15.7 \mathrm{~Hz}, \mathrm{CH}$ vinyl), $5.86(1 \mathrm{H}, \mathrm{m}, \mathrm{CH}$ vinyl), 4.31 (2H, m, subst $\mathrm{Cp}), 4.20$ (2H, m, subst $\mathrm{Cp}), 4.02$ (5H, s, Cp), 3.63 (2H, br d, J = $7 \mathrm{~Hz}, \mathrm{C}_{2}$-vinyl), $2.33\left(6 \mathrm{H}, \mathrm{s}, \mathrm{CH}_{3}\right) .{ }^{13} \mathrm{C}\left(125 \mathrm{MHz}, \mathrm{CDCl}_{3}\right): 138.4$ (s, quat. Ar), 135.6 (s, quat. Ar), 130.3 (s, CH vinyl), 129.0 (s, Ar), 128.2 (s, 2C Ar), 122.3 (s, CH vinyl), 82.6 (s, quat. Cp), 69.2 (s, Cp), 68.6 (s, subst. Cp), 66.7 (s, subst. Cp), 36.8(s, $\underline{\mathrm{C}} \mathrm{H}_{2}$-vinyl), 21.3 (s, 2C $\underline{\mathrm{CH}}_{3}$ ). HR MS (ESI+): 362.0792 (100\%, 362.0792 for $\left.\mathrm{C}_{21} \mathrm{H}_{22} \mathrm{FeS}: \mathrm{M}\right), 225.0372$ (40\%, 225.0367 for $\mathrm{C}_{13} \mathrm{H}_{13} \mathrm{Fe}$ : M-SAr).

\section{Reaction with iPrSH}

$27 \mathrm{mg}$ of $\mathbf{2 d}(36 \%)$ and $88 \mathrm{mg}$ of $\mathbf{3 d}(50 \%)$ as yellow solids (procedure B).

$67 \mathrm{mg}$ of $\mathbf{2 d}(89 \%)$ and $3 \mathrm{mg}$ of $\mathbf{3 d}(4 \%)$ as yellow solids (procedure C).

(2-ferrocenylvinyl)methyl isopropyl sulfide $2 \mathrm{~d}$ : ${ }^{1} \mathrm{H}\left(400 \mathrm{MHz}, \mathrm{CDCl}_{3}\right): 6.21(1 \mathrm{H}, \mathrm{br} \mathrm{d}, \mathrm{J}=$ $15.5 \mathrm{~Hz}, \mathrm{CH}$ vinyl), 5.81 (1H, d of $\mathrm{t}, \mathrm{J}=15.5 \mathrm{~Hz}, \mathrm{~J}=7.4 \mathrm{~Hz}, \mathrm{CH}$ vinyl), 4.34 (2H, pseudo $\mathrm{t}, \mathrm{J}=$ $1.9 \mathrm{~Hz}$, subst Cp), $4.22(2 \mathrm{H}$, pseudo t, $\mathrm{J}=1.9 \mathrm{~Hz}$, subst Cp), $4.11(5 \mathrm{H}, \mathrm{s}, \mathrm{Cp}), 3.25(2 \mathrm{H}, \mathrm{dd}, \mathrm{J}$ $\left.=7.4 \mathrm{~Hz}, \mathrm{~J}=1.3 \mathrm{~Hz} \mathrm{CH}_{2}\right), 2.96(1 \mathrm{H}$, hept, $\mathrm{J}=6.7 \mathrm{~Hz}, \mathrm{CH}), 1.32\left(6 \mathrm{H}, \mathrm{d}, \mathrm{J}=6.7 \mathrm{~Hz}, \mathrm{CH}_{3}\right) .{ }^{13} \mathrm{C}$ (125 MHz, $\mathrm{CDCl}_{3}$ ): 129.2 (s, $\mathrm{CH}$ vinyl), 123.5 (s, $\mathrm{CH}$ vinyl), 82.9 (s, quat. Cp), 69.2 (s, Cp), 68.6 (s, subst. Cp), 66.7 (s, subst. Cp), 33.6 (s, CH), 33.5 (s, $\underline{\mathrm{CH}}_{2}$-vinyl), 23.3 (s, $\mathrm{CH}_{3}$ ). HR MS (ESI+): 300.0638 (100\%, 300.0635 for $\mathrm{C}_{16} \mathrm{H}_{20} \mathrm{FeS}$ : M), 225.0373 (19\%, 225.0367 for $\left.\mathrm{C}_{13} \mathrm{H}_{13} \mathrm{Fe}: \mathrm{M}-\mathrm{SAr}\right)$.

(R/S)-(ferrocenyl)(vinyl)methyl isopropyl sulfide 3d: ${ }^{1} \mathrm{H}\left(400 \mathrm{MHz}, \mathrm{CDCl}_{3}\right): 6.00(1 \mathrm{H}, \mathrm{m}$, $\mathrm{CH}$ vinyl), 5.17-5.08 (2H, m, CH vinyl), 4.26-4.13 (5H, m, 4H subst $\mathrm{Cp}+1 \mathrm{H}$ C- -vinyl), 4.21 $(5 \mathrm{H}, \mathrm{s}, \mathrm{Cp}), 2.86\left(1 \mathrm{H}, \mathrm{m}, \mathrm{CHCH}_{3}\right), 1.31\left(3 \mathrm{H}, \mathrm{d}, \mathrm{J}=6.5 \mathrm{~Hz}, \mathrm{CH}_{3}\right), 1.26\left(3 \mathrm{H}, \mathrm{d}, \mathrm{J}=6.5 \mathrm{~Hz}, \mathrm{CH}_{3}\right)$. ${ }^{13} \mathrm{C}\left(125 \mathrm{MHz}, \mathrm{CDCl}_{3}\right.$ ): 138.6 (s, $\mathrm{CH}$ vinyl), 114.1 (s, $\mathrm{CH}$ vinyl), 88.0 (s, quat. $\mathrm{Cp}$ ), 68.8 (s, Cp), 67.9 (s, subst. Cp), 67.6 (s, subst. Cp), 67.5 (s, subst. Cp), 66.5 (s, subst. Cp), 47.1 (s, CH- 
vinyl), 34.3 (s, $\underline{\mathrm{CHCH}} 3$ ), 23.7 (s, $\mathrm{CH}_{3}$ ), 22.9 (s, $\mathrm{CH}_{3} \mathrm{HR}$ MS (ESI+): 300.0638 (100\%, 300.0635 for $\left.\mathrm{C}_{16} \mathrm{H}_{20} \mathrm{FeS}: \mathrm{M}\right), 225.0373$ (19\%, 225.0367 for $\mathrm{C}_{13} \mathrm{H}_{13} \mathrm{Fe}$ : M-SAr).

\section{Réaction with tBuSH}

$74 \mathrm{mg}(94 \%)$ as a 44/56 mixture of $\mathbf{2 e}$ and $\mathbf{3 e}$ (procedure B).

$68 \mathrm{mg}(87 \%)$ as a 84/16 mixture of $\mathbf{2 e}$ and $\mathbf{3 e}$ (procedure B).

HR MS (ESI+): 314.0792 (100\%, 314.0792 for $\left.\mathrm{C}_{17} \mathrm{H}_{22} \mathrm{FeS}: \mathrm{M}\right), 225.0369$ (26\%, 225.0367 for $\left.\mathrm{C}_{13} \mathrm{H}_{13} \mathrm{Fe}: \mathrm{M}-\mathrm{SAr}\right)$.

(2-ferrocenylvinyl)methyl tert-butyl sulfide $2 \mathrm{e}:{ }^{1} \mathrm{H}\left(400 \mathrm{MHz}, \mathrm{CDCl}_{3}\right): 6.28(1 \mathrm{H}, \mathrm{d}$ of $\mathrm{t}, \mathrm{J}=$ $15.5 \mathrm{~Hz}, \mathrm{~J}=1.4 \mathrm{~Hz}, \mathrm{CH}$ vinyl), $5.85(1 \mathrm{H}, \mathrm{d}$ of $\mathrm{t}, \mathrm{J}=15.5 \mathrm{~Hz}, \mathrm{~J}=7.3 \mathrm{~Hz}, \mathrm{CH}$ vinyl), 4.33 (2H, pseudo t, J = 1.9 Hz, subst Cp), 4.21 (2H, m, subst Cp), 4.21 (5H, s, Cp), 3.30 (2H, dd, J = 7.3 $\left.\mathrm{Hz}, \mathrm{J}=1.4 \mathrm{~Hz} \underline{\mathrm{C}}_{2}\right), 1.404\left(9 \mathrm{H}, \mathrm{s}, \mathrm{CH}_{3}\right) .{ }^{13} \mathrm{C}\left(125 \mathrm{MHz}, \mathrm{CDCl}_{3}\right): 129.4$ (s, CH vinyl), 123.9 (s, CH vinyl), 83.0 (s, quat. Cp), 69.1 (s, Cp), 68.5 (s, subst. Cp), 66.6 (s, subst. Cp), 31.8 (s, $\underline{\mathrm{CH}}_{2}$ ), $31.6\left(\mathrm{~s}, \underline{\mathrm{CCH}_{3}}\right), 31.1\left(\mathrm{~s}, \mathrm{CH}_{3}\right)$.

(R/S)-(ferrocenyl)(vinyl)methyl tert-butyl sulfide $3 \mathbf{e}:{ }^{1} \mathrm{H}\left(400 \mathrm{MHz}, \mathrm{CDCl}_{3}\right): 6.16(1 \mathrm{H}, \mathrm{m}$, CH vinyl), 5.23 (1H, br d, J = 17.0 Hz, CH vinyl), 5.16 (1H, br d, J = 10.0 Hz, CH vinyl), 4.3$4.1(5 \mathrm{H}, \mathrm{m}, 4 \mathrm{H}$ subst $\mathrm{Cp}+1 \mathrm{H} \mathrm{CH}), 4.21(5 \mathrm{H}, \mathrm{s}, \mathrm{Cp}), 1.395\left(9 \mathrm{H}, \mathrm{s}, \mathrm{CH}_{3}\right) .{ }^{13} \mathrm{C}(125 \mathrm{MHz}$, $\mathrm{CDCl}_{3}$ ): 141.4 (s, CH vinyl), 114.0 (s, CH vinyl), 89.6 (s, quat. $\mathrm{Cp}$ ), 68.8 (s, Cp), 67.9 (s, subst. Cp), 67.64 (s, subst. Cp), 67.61 (s, subst. Cp), 67.0 (s, subst. Cp), 45.8 (s, CH), 31.6 (s, $\underline{\mathrm{CCH}}_{3}$ ), $31.1\left(\mathrm{~s}, \mathrm{CH}_{3}\right)$.

\subsection{X-ray structural analyses of $2 \boldsymbol{a}$ and $2 \boldsymbol{b}$}

A single crystal of each compound was mounted under inert perfluoropolyether at the tip of a glass fibre and cooled in the cryostream of a Rigaku Oxford-Diffraction GEMINI EOS diffractometer.

The structures were solved by direct methods $\left(\operatorname{SIR} 97^{45}\right)$ and refined by least-squares procedures on $F^{2}$ using SHELXL-97. ${ }^{46}$ All $\mathrm{H}$ atoms attached to carbon were introduced in calculated positions and treated as riding models. The absolute structure for compounds $\mathbf{2} \mathbf{a}$ has been evaluated by refining the Flack's parameter. ${ }^{47}$ The drawing of the molecules was realised with the help of ORTEP32. ${ }^{48,49}$ Crystal data and refinement parameters are shown in Table 4. 
Table 4: Crystal Data

\begin{tabular}{|c|c|c|}
\hline Identification code & $2 \mathbf{2 a}$ & $2 \mathbf{b}$ \\
\hline Empirical formula & $\mathrm{C}_{38} \mathrm{H}_{36} \mathrm{Fe}_{2} \mathrm{~S}_{2}$ & $\mathrm{C}_{23} \mathrm{H}_{20} \mathrm{FeS}$ \\
\hline Formula weight & 668.49 & 384.30 \\
\hline Temperature, $\mathrm{K}$ & 173(2) & 173(2) \\
\hline Wavelength, $\AA$ & 0.71073 & 0.71073 \\
\hline Crystal system & Orthorhombic & Monoclinic \\
\hline Space group & Fdd2 & $\mathrm{P} 2{ }_{1} / \mathrm{c}$ \\
\hline $\mathrm{a}, \AA$ & $51.2494(10)$ & $5.8000(2)$ \\
\hline $\mathrm{b}, \AA$ & $40.5129(9)$ & 14.9194(4) \\
\hline $\mathrm{c}, \AA$ & $5.94660(10)$ & $20.6292(5)$ \\
\hline$\alpha,{ }^{\circ}$ & 90.0 & 90.0 \\
\hline$\beta,^{\circ}$ & 90.0 & $91.410(2)$ \\
\hline$\gamma,^{\circ}$ & 90.0 & 90.0 \\
\hline Volume, $\AA^{3}$ & $12346.7(4)$ & $1784.56(9)$ \\
\hline $\mathrm{Z}$ & 16 & 4 \\
\hline Density (calc), $\mathrm{Mg} / \mathrm{m}^{3}$ & 1.439 & 1.430 \\
\hline Abs. coefficient, $\mathrm{mm}^{-1}$ & 1.102 & 0.964 \\
\hline $\mathrm{F}(000)$ & 5568 & 800 \\
\hline Crystal size, $\mathrm{mm}^{3}$ & $0.370 \times 0.130 \times 0.130$ & $0.180 \times 0.100 \times 0.050$ \\
\hline Theta range, ${ }^{\circ}$ & 3.120 to 26.369 & 2.904 to 26.372 \\
\hline Reflections collected & 30927 & 18623 \\
\hline Indpt reflections $\left(\mathrm{R}_{\text {int }}\right)$ & $5981(0.026)$ & $3643(0.0314)$ \\
\hline Completeness, $\%$ & 99.7 & 99.6 \\
\hline Absorption correction & Multi-scan & Multi-scan \\
\hline Max. / min. transmission & $1.0 / 0.914$ & 1.0 and 0.944 \\
\hline Refinement method & $\mathrm{F}^{2}$ & $\mathrm{~F}^{2}$ \\
\hline Data/restraints/parameters & $5981 / 1 / 379$ & $3643 / 0 / 226$ \\
\hline Goodness-of-fit on $\mathrm{F}^{2}$ & 1.044 & 1.028 \\
\hline $\mathrm{R} 1, \mathrm{wR} 2[\mathrm{I}>2 \sigma(\mathrm{I})]$ & $0.0210,0.0469$ & $0.0315,0.0717$ \\
\hline R1, wR2 (all data) & $0.0231,0.0477$ & $0.0389,0.0751$ \\
\hline Flack's parameter & $-0.012(4)$ & \\
\hline Residual density, e. $\AA^{-3}$ & $0.188 /-0.169$ & $0.934 /-0.285$ \\
\hline
\end{tabular}


Crystallographic data for compounds $\mathbf{2 a}$ and 2 b (excluding structure factors) have been deposited with the Cambridge Crystallographic Data Centre as supplementary publication no. CCDC 1542978-1542979. Copies of the data can be obtained free of charge on application to the Director, CCDC, 12 Union Road, Cambridge CB2 1EZ, UK (fax: (+44) 1223-336-033; email: deposit@ccdc.cam.ac.uk).

Computational Details. The calculations were carried out within the DFT approach with the B97D functional, including an ultrafine integration grid, as implemented in Gaussian 09. All geometry optimizations were carried out using the SDD basis set and ECP for the Fe atom, augmented with an $\mathrm{f}$ polarization function $(\alpha=2,462),{ }^{50}$ and the $6-31 \mathrm{G}(\mathrm{d}, \mathrm{p})$ basis sets for all other atoms. The effect of the solvent was included by the SMD polarisable continuum ${ }^{51}$ in ethanol ( $\varepsilon=24.852)$ during the geometry optimizations. All of the energies presented in the text are Gibbs energies in ethanol $\left(\Delta \mathrm{G}_{\mathrm{EtOH}}\right)$.

\section{Acknowledgements}

We thank the Centre National de la Recherche Scientifique (CNRS) for support. RB thanks the "Ministère de l'Enseignement Supérieur et la Recherche Scientifique" of Algeria for generous funding of her Internship in Toulouse. This work was granted access to the HPC resources of IDRIS under the allocation 2016-086343 made by GENCI (Grand Equipement National de Calcul Intensif) and to the resources of the CICT (Centre Interuniversitaire de Calcul de Toulouse, project CALMIP).

\section{References}

${ }^{1}$ Y. Yatsumonji, Y. Ishida, A. Tsubouchi, T. Takeda Org. Lett., 2007, 9, 4603-4606.

2 A. B. Zaitsev, H. F. Caldwell, P. S. Pregosin, L. F. Veiros Chem. Eur. J., 2009, 15, 6468 6477.

${ }^{3}$ S. Tanaka, P. K. Pradhan, Y. Maegawa, M. Kitamura Chem. Commun., 2010, 46, 39963998.

${ }^{4}$ F. Robertson, J. Wu Org. Lett., 2010, 12, 2668-2671.

${ }^{5}$ N. Gao, S. Zheng, W. Yang, X. Zhao Org. Lett., 2011, 13, 1514-1516.

${ }^{6}$ J. A. van Rijn, M. C. Guijt, D. de Vries, E. Bouwman, E. Drent Appl. Organometal. Chem. 2011, 25, 212-219. 
${ }^{7}$ M. Roggen, Erick M. Carreira Angew. Chem. Int. Ed. 2012, 51, 8652 -8655.

${ }^{8}$ V. Pace, L. Castoldi, W. Holzer Tet.Lett., 2012, 53, 967-972.

${ }^{9}$ S. Banerjee, L. Adak, B. C. Ranu Tet. Lett., 2012, 53, 2149-2153.

${ }^{10}$ P. N. Chatterjee, S. Roy Tetrahedron, 2012, 68, 3776-3785.

${ }^{11}$ L. Herkert, S. L. J. Green, G. Barker, D. G. Johnson, P. C. Young, S. A. Macgregor, A.-L. Lee Chem. Eur. J., 2014, 20, 11540 - 11548.

${ }^{12}$ G. Tabarelli, M.Godoi, R. F. S. Canto, J. R. Mora, F. Nome, A. L. Braga Synth. Commun., 2014, 44, 3441-3449.

${ }^{13}$ A. B. Pritzius, B. Breit Angew. Chem. Int. Ed., 2015, 54, 3121 -3125.

${ }^{14}$ B. B. Aggarwal, S. Shishodia Biochem. Pharmacology, 2006, 71, 1397-1421.

15 (b) L. Brunsveld, J. Kuhlmann, K. Alexandrov, A. Wittinghofer, R. S. Goody, H. Waldmann Angew. Chem. Int. Ed. , 2006, 45, 6622 - 6646.

${ }^{16}$ J. He, M. Zha, J. Cui, M. Zeller, A. D. Hunter, S.-M. Yiu, S.-T. Lee, Z. Xu J. Am. Chem. Soc., 2013, 135, 7807-7810.

${ }^{17}$ R. Malherbe, G. Rist, D. Bellus J. Org. Chem., 1983, 48, 860-869..

${ }^{18}$ E. Vedejs Acc. Chem. Res., 1984, 135, 7807-7810.

${ }^{19}$ R. Oehrlein, R. Jeschke, B. Ernst, D. Bellus Tet. Lett., 1989, 30, 3517-3520.

${ }^{20}$ S. Barluenga, P. Lopez, E. Moulin, N. Winssinger Angew. Chem. Int. Ed., 2004, 43, 3467 3470.

${ }^{21}$ D. Crich, Y. Zou, F. Brebion J. Org. Chem., 2006, 71, 9172-9177.

${ }^{22}$ Y. A. Lin, J. M. Chalker, N. Floyd, G. J. L. Bernardes, B. G. Davis J. Am. Chem. Soc., 2008, 130, 358-364.

${ }^{23}$ T. J. Colacot Chem. Rev. 2003, 103, 3101-3118.

${ }^{24}$ R. C. J. Atkinson, V. C. Gibson, N. J. Long Chem. Soc. Rev. 2004, 33, 313-328.

${ }^{25}$ R. Gomez Arrayas, J. Adrio, J. C. Carretero, Angew. Chem.Int. Ed. 2006, 68, 3679.

${ }^{26}$ A. Fihri, P. Meunier, J.-C. Hierso Coord. Chem. Rev. 2007, 251, 2017-2055.

27 W. Chen, H.-U. Blaser, "Ligands with planar chirality: planar chiral ferrocene-and paracyclophane-based diphosphines" ed. by A. Börner (Wiley-VCH, Weinheim, Germany), 2008 345-359.

${ }^{28}$ P. Stepnicka, M. Lamac, "Synthesis and catalytic use of planar chiral and polydentate ferrocene donors" ed. by P. Stepnicka (John Wiley, Chichester, UK), 2008, 345-359.

29 E. Manoury, R. Poli, "Phosphine-Containing Planar Chiral ferrocenes: Synthesis, Coordination Chemistry and Applications to Asymmetric Catalysis." in the Series: Catalysis by Metal Complexes (CMCO), Volume 36 (Phosphorus Chemistry: Catalysis and Material Science Applications), ed. by M. Peruzzini and L. Gonsalvi (Springer Verlag, Germany), 2011, 121-149.

${ }^{30}$ S. Toma, J. Csizmadiova, M. Meciarova, R. Sebesta Dalton Trans., 2014, 43, 16557-16579.

${ }^{31}$ R. Sun, L. Wang, H. Yu,. Z. Abdin, Y. Chen, J. Huang, R. Tong Organometallics, 2014, 33, 4560-4573.

${ }^{32}$ L. Peng, A. Feng, M. Huo, J. Yuan Chem. Commun., 2014, 50, 13005-13014.

${ }^{33}$ S. S. Braga, A. M. S. Silva Organometallics, 2013, 32, 5626-5639.

${ }^{34}$ V. N. Babin, Yu. A. Belousov, V. I. Borisov, V. V. Gumenyuk, Yu. S. Nekrasov, L. A.

Ostrovskaya, I. K. Sviridova, N. S. Sergeeva, A. A. Simenel, L. V. Snegur Russ. Chem. Bull., Int. Ed., 2014, 63, 2405-2422.

${ }^{35}$ R. Bouchene, J.-C. Daran, S. Bouacida, E. Manoury, Eur. J. Inorg. Chem., 2017, 340-350.

${ }^{36}$ G. A. Olah, D. H. O’Brien, C. U. Pittmann, Jr, J. Am. Chem., 1967, 89, 2996-3001.

${ }^{37}$ P. Bonvicini, A. Levi, V. Lucchini, G. Scorrano, J. Chem.Soc. Perkin II, 1972, 2267-2269. 
${ }^{38}$ M. Eckert-Maksic, R. Boscovic, J. Chem.Soc. Perkin II, 1981, 62-64.

${ }^{39}$ P. Traldi, J. Heterocyclic Chem., 1989, 26, 465-468.

${ }^{40}$ For the pKa of thiol/thiolate couples, see: B. Thapa, H. B. Schlegel, J. Phys.. Chem. A, 2016, 120, 5726-5735 and references herein.

${ }^{41}$ M. B. Smith and J. March, March's Advanced Organic Chemistry: Reactions, Mechanisms, and Structure 6th edn (John Wiley \& Sons, Hoboken, NJ), 2007, 469-473.

${ }^{42}$ S. Zhang, J. Comput. Chem., 2011, 33, 517-526.

${ }^{43}$ A. L. Spek, J. Appl. Cryst., 2003, 36, 7-13.

${ }^{44}$ A. Z. Kreidlin, F. M. Dolgushin, A. I. Yanovsky, Z. A. Kerzina, P. V. Petrovskii, J. Organomet. Chem. 2000, 616, 106-111.

${ }^{45}$ A. Altomare, M. C. Burla, M. Camalli, G. L. Cascarano, C. Giacovazzo, A. Guagliardi, A. G. G. Moliterni, G. Polidori, R. Spagna, SIR97- a program for automatic solution of crystal structures by direct methods. J. Appl. Cryst., 1999, 32, 115-119.

${ }^{46}$ G. M. Sheldrick, Acta Cryst., 2008, A64, 112-122.

${ }^{47}$ H. D. Flack, Acta Cryst. , 1983, A39, 876-881.

${ }^{48}$ L. J. Farrugia, “ORTEP-3 for Windows”, J. Appl. Cryst., 1997, 30, 565.

${ }^{49}$ M. N. Burnett, C. K. Johnson, “ORTEPIII” Report ORNL-6895, 1996, Oak Ridge National Laboratory, Tennessee, USA

${ }^{50}$ A. W. Ehlers, M. Boehme, S. Dapprich, A. Gobbi, A. Hoellwarth, V. Jonas, K. F. Koehler, R. Stegmann, A. Veldkamp, G. Frenking, Chem. Phys. Lett., 1993, 208, 111-114.

${ }^{51}$ A. V. Marenich, C. J. Cramer, D. G. Truhlar, J. Phys. Chem. B, 2009, 113, 6378-6396. 